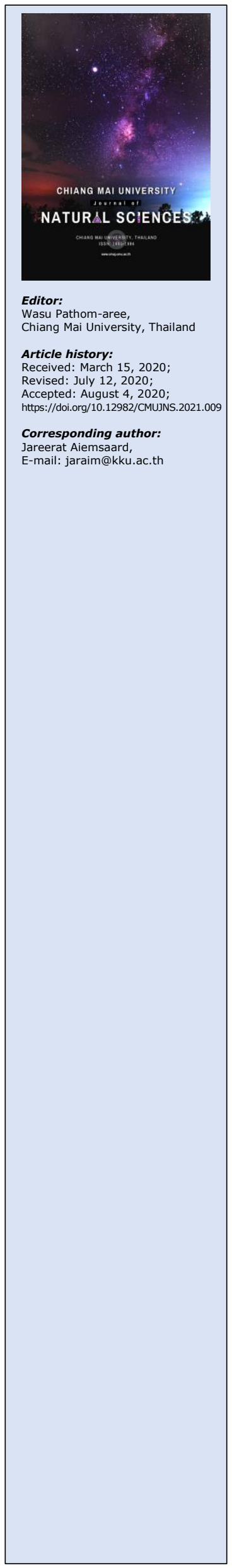

Research article

\title{
The Effect of Some Essential Oils Against Subclinical Mastitis Bacteria Isolated from Dairy Goats
}

\author{
Jareerat Aiemsaard*, Chaiwat Jarassaeng, and Eakachai Thongkham
}

Faculty of Veterinary Medicine, Khon Kaen University, Khon Kaen 40002, Thailand.

Abstract The bacteria causing mastitis in goats reduce the quality of milk products resulting in economic losses and the use of antiseptic agents leave residues in the milk. Therefore, this study investigated the antibacterial activity of lemongrass, kaffir lime and holy basil essential oils against subclinical mastitis bacterial isolates from dairy goats. A total of 47 bacteria were isolated, consisting of 40 staphylococci (34 coagulase-negative staphylococci (CNS), 5 S. aureus and 1 S. epidermidis), 4 a-Streptococcus spp., 2 Bacillus spp. and 1 Alcaligenes faecalis. The main components of essential oil of lemongrass were geranial, neral, myrcene and geraniol (45.32-4.12\%), kaffir lime consisted of $\beta$-pinene, DLlimonene, terpinene-4-ol and $\alpha$-terpineol (25.58-12.24\%) and holy basil consisted of methyl eugenol, caryophyllene and eugenol (52.43-8.68\%). Lemongrass essential oil showed the highest antibacterial activity against CNS and S. aureus with average inhibition zone diameters of $25.00 \pm 1.75$ and $31 \pm 6.61 \mathrm{~mm}$, respectively, and minimum inhibitory concentration for $90 \%$ of tested samples ( MIC $_{90}$ ) and minimum bactericidal concentration for $90 \%$ of tested samples ( $\mathrm{MBC}_{90}$ ) values at least eight fold less than kaffir lime and holy basil essential oils. The time-kill assay demonstrated that lemongrass essential oil at 5-10 times MIC 90 reduced the survival of $S$. aureus by 99.9 and $99.99 \%$ respectively within $30 \mathrm{~min}$, a greater reduction than seen for $0.54 \% \mathrm{w} / \mathrm{v}$ iodine solution. The results of this study show that lemongrass essential oil has the potential to be developed as an antibacterial agent or teat dip formula for control of subclinical mastitis in goats.

Keywords: Antibacterial activity, Essential oil, Mastitis

Funding: This work was supported by the Faculty of Veterinary Medicine, Khon Kaen University.

Citation: Aiemsaard, J., Jarassaeng, C., and Thongkham, E. 2021. The effect of some essential oils against subclinical mastitis bacteria isolated from dairy goats. CMUJ. Nat. Sci. 20(1): e2021009. 


\section{INTRODUCTION}

Goat milk and goat milk products appeal to consumers because they are highly nutritious and have health benefits. However, the problem of subclinical mastitis due to bacterial infection in dairy goats, which causes microbial contamination of the milk resulting in reduced quality of milk products and economic loss (Conteras et al., 2003; Ali et al., 2010; Sharma et al., 2010), is increasing (McDougall et al., 2002; Persson and Olofsson, 2011; Islam et al., 2012). Moreover, consumption of pathogens in contaminated milk can cause disease in humans (Wakwoya et al., 2006; Gamboa, 2009). The main pathogens that cause subclinical mastitis in dairy goats are coagulasenegative staphylococci (CNS) and Staphylococcus aureus (Taufik et al., 2008; Aydin et al., 2009; Virdis et al., 2010; Mishra et al., 2018).

Several antibiotics are currently used to treat mastitis in goats, but their use can increase the incidence of drug-resistant bacteria and also cause antibiotic residue problems in milk products (Adwan, 2006; Virdis et al., 2010). Therefore, the prevention of external infection to the teat by using pre- and post-milking teat dipping antiseptic is very important (Singh et al., 2018). However, the antiseptics commonly used are synthetic chemicals, which can leave residues in milk that affect the health of consumers and the quality of milk products (Dahl et al., 2003; Hebert et al., 2003). Because of these problems, antimicrobial agents from herbs are interesting alternatives to synthetic antimicrobial drugs or antiseptics, especially when used for pre- or postmilking teat dipping, as they can be very safe when used in suitable forms and concentrations.

Many natural substances have been shown to have antibacterial activity such as propolis, tannin and essential oils (Min et al., 2008; Santos Neto et al., 2009). Essential oils contain various chemical constituents such as monoterpenes, sesquiterpenes, diterpenes, and other aromatic or aliphatic compounds (Dhifi et al., 2016) that have therapeutic properties such as antibacterial, antifungal, anti-inflammatory and antioxidation activities. Also, they are safe to use, easy to prepare, inexpensive, and there has been no report of resistance among mastitis pathogens (Burt et al., 2004). There is one report showing that the essential oils of lemongrass, kaffir lime and holy basil are effective against the bacteria that cause mastitis in dairy cows (Aiemsaard et al., 2010), but there is no previous report about their efficacy in goats. Therefore, we studied the antibacterial activity of essential oils from three Thai herbs namely: lemongrass (Cymbopogon citratus), kaffir lime (Citrus hystrix), and holy basil (Ocimum sanctum), against subclinical mastitis bacteria isolated from dairy goat.

\section{MATERIALS AND METHODS}

\section{Bacterial isolation and culture conditions}

Raw milk samples were collected from dairy goats that had not received any antibiotics at least 14 days before collection and had been diagnosed with subclinical mastitis by a farm veterinarian. Samples were collected from affected quarters of the udder. The udder was cleaned with $50 \mathrm{ppm}$ chlorine solution and the nipples were wiped with rubbing alcohol. The first $10-15 \mathrm{ml}$ of milk was discarded before $3-5 \mathrm{ml}$ milk samples were collected in sterile test tubes and stored at $4^{\circ} \mathrm{C}$ in a temperaturecontrolled container. Upon reaching the laboratory, the milk samples were cultured on blood agar and MacConkey agar (Becton Dickinson, USA) and incubated at $37^{\circ} \mathrm{C}$ for 24 $48 \mathrm{~h}$ (Markey et al., 2013; Mohammed 2014). The bacteria growing on culture media were identified by gram staining and routine biochemical testing at the Veterinary Diagnostic Laboratory, Animal Hospital Khon Kaen University, Thailand. The biochemistry tests including catalase test, oxidase test, motility test, coagulase test, urease tests, oxidation-fermentation test, carbohydrate fermentation test, aesculin hydrolysis test, indole test, methyl red test, citrate test and Voges-Proskauer test.

Before testing, the bacteria were transferred to Mueller Hinton broth (MHB, Becton Dickinson, France) and incubated at $37^{\circ} \mathrm{C}$ for $24 \mathrm{~h}$. The optical density (OD) at $600 \mathrm{~nm}$ of bacterial suspensions was measured by Vis-spectrophotometer (Genesys 10 VIS, 
Thermo Scientific, USA) and the bacterial concentration was adjusted to $10^{6} \mathrm{CFU} / \mathrm{ml}$, which was confirmed by viable counts (Usman et al., 2013).

\section{Determination of chemical composition by gas chromatography- mass spectrometry (GC-MS) analysis}

The essential oils of lemongrass, kaffir lime and holy basil were purchased from Thai-China Flavours and Fragrances Industry Co., Ltd., Thailand. The GC-MS analysis was performed according to the method previously described by Aiemsaard et al. (2010) and Amelia et al. (2017) with modifications for the Agilent CN10402086 gas chromatograph interfaced with the Agilent US35120381 mass spectrometer. Each essential oil was diluted with hexane (Merck, Germany) before injection into the GC-MS using a DB-5ms fused silica capillary column ( $30 \mathrm{~m} \times 25 \mathrm{~mm}$, film thickness $0.25 \mu \mathrm{m}$ ). The carrier gas was helium with a flow rate of $1 \mathrm{ml} / \mathrm{min}$. The start temperature was $70^{\circ} \mathrm{C}$ for $5 \mathrm{~min}$. The temperature was increased at a rate of $3^{\circ} \mathrm{C} / \mathrm{min}$ to $120^{\circ} \mathrm{C}$ and held for $2 \mathrm{~min}$, then from 120 to $270^{\circ} \mathrm{C}$ at a rate of $5^{\circ} \mathrm{C} / \mathrm{min}$ and held for $17 \mathrm{~min}$. The chemical constituents of the essential oils were identified by comparing with reference retention times.

\section{Determination of antibacterial activity by disc diffusion method}

The inhibition zones for lemongrass, kaffir lime and holy basil essential oils against CNS $(n=34)$ and S. aureus $(n=5)$ subclinical mastitis isolates were determined by the disc diffusion method according to the Clinical and Laboratory Standard Institute (CLSI) recommendations (2013) with modifications. Briefly, bacterial suspensions at a concentration of $10^{6} \mathrm{CFU} / \mathrm{ml}$ were inoculated onto Mueller Hinton agar plates (MHA, Becton Dickinson, France) by streak plate technique. Then, sterile Whatman filter paper no. 1 discs ( $6 \mathrm{~mm}$ diameter) with $10 \% \mathrm{v} / \mathrm{v}$ essential oil diluted in dimethyl sulfoxide (DMSO, V.S. Chem House, Thailand) $(20 \mu \mathrm{l} / \mathrm{disc})$ were placed on the inoculated surface. The plates were incubated at $37^{\circ} \mathrm{C}$ for $24 \mathrm{~h}$. The inhibition zones were measured using a ruler. All tests were performed in triplicate. All data are reported as the mean \pm standard deviation.

\section{Determination of antibacterial activity by broth microdilution method}

The MICs and MBCs of lemongrass, kaffir lime and holy basil essential oils against CNS $(n=34)$ and S. aureus $(n=5)$ subclinical mastitis isolates were determined by the broth microdilution method according to CLSI recommendations (2008) with modifications. Briefly, serial dilutions of tested substances $(2.5-0.00488 \% \mathrm{v} / \mathrm{v})$ were prepared with $\mathrm{MHB}$ in 96 -well flat-bottomed microtiter plates (Costar ${ }^{\circledR}$, Corning Incorporated). Then, a $10^{6} \mathrm{CFU} / \mathrm{ml}$ bacterial suspension was added into each well. Wells containing bacteria cultured without tested agents served as positive growth control wells and wells containing tested agents without bacteria served as negative growth control wells. The plates were incubated at $37^{\circ} \mathrm{C}$ for $24 \mathrm{~h}$. All tests were performed in triplicate. The MIC was defined as the lowest concentration of essential oil that prevented visible growth after $24 \mathrm{~h}$ of incubation. Ten microliter samples from the wells with no visible growth were inoculated onto MHA and incubated at $37^{\circ} \mathrm{C}$ for $24 \mathrm{~h}$. The $M B C$ was determined from the lowest concentration of essential oil that showed no growth on MHA. The $\mathrm{MIC}_{90}$ and $\mathrm{MBC}_{90}$ were defined as the concentrations of essential oils that inhibited growth or killed bacteria in $90 \%$ of tested isolates, respectively.

\section{Determination of time-kill kinetics of lemongrass essential oil against a $S$. aureus subclinical mastitis isolate}

The essential oil which showed the highest antibacterial activity against both CNS and $S$. aureus in the broth microdilution test was determined the time-kill kinetics against a $S$. aureus subclinical mastitis isolate by time-kill test. S. aureus was selected to test in this study since it is the major identified pathogen and has virulent more than others. The study was performed according to the method of Chamdit and Siripermpool (2012) with modifications. Briefly, a $100 \mu$ aliquot of bacterial suspension $\left(10^{6} \mathrm{CFU} / \mathrm{ml}\right)$ was added to tubes containing the essential oil at final concentrations of 1,5 and 10 times MIC $_{90}$, then mixed on a vortex mixer for $1 \mathrm{~min}$. After $0.5,1,2,3,4,5$ and $6 \mathrm{~h}$ of 
incubation at $37^{\circ} \mathrm{C}$, the mixtures were diluted 10 -fold with $0.89 \%$ sodium chloride solution to stop the antimicrobial effects of the essential oil. A $100 \mu \mathrm{l}$ aliquot of the $10^{-1}$ to $10^{-4}$ dilutions of each tube was spread onto MHA plates, which were incubated at $37^{\circ} \mathrm{C}$ for $24 \mathrm{~h}$. The colonies of visible growth of tested microorganisms were counted and recorded. A $0.54 \% \mathrm{w} / \mathrm{v}$ iodine solution (Masodine ${ }^{\circledR}$, Evans Vanodine International, UK), which is a widely used pre- and post-milking teat disinfectant, was used for the internal standard antibacterial control. The experiment was performed in triplicate. All data are reported as the mean \pm standard deviation.

\section{Statistical analysis}

Each experiment was performed in triplicate. One-way ANOVA was used to compare means $(a=0.05)$. All analyses were performed using SPSS for windows version 19.0 (SPSS Inc., USA), KKU license.

\section{RESULTS}

\section{Dairy goat subclinical mastitis bacterial isolates}

A total of 47 bacteria were isolated from 21 affected quarters of dairy goat udders with subclinical mastitis (Table 1 ). Staphylococci were the most commonly isolated bacteria with 40 isolates $(85.10 \%)$, followed by a-Streptococcus spp. (4 isolates, $8.51 \%$ ), Bacillus spp. (2 isolates, $4.26 \%$ ) and Alcaligenes faecalis (1 isolate, $2.13 \%$ ). The staphylococci bacteria could be further divided into 34 CNS (72.34\%) consisting of 26 unidentified Staphylococcus spp., 5 S. xylosus, and 1 each of S. cohini, S. capitis and S. caprae, and 6 coagulase-positive staphylococci consisting of $5 \mathrm{~S}$. aureus $(10.63 \%)$ and 1 S. intermedius.

Table 1. The bacteria isolated from dairy goats with subclinical mastitis.

\begin{tabular}{ll}
\hline Bacterial species & Number of isolates \\
\hline Staphylococci & \\
Coagulase-positive staphylococci & \\
S. aureus & $5(10.63 \%)$ \\
S. intermedius & $1(2.13 \%)$ \\
Coagulase-negative staphylococci & \\
Staphylococcus spp. & $26(55.32 \%)$ \\
S. xylosus & $5(10.63 \%)$ \\
S. cohini & $1(2.13 \%)$ \\
S. capitis & $1(2.13 \%)$ \\
S. caprae & $1(2.13 \%)$ \\
a-Streptococcus spp. & $4(8.51 \%)$ \\
Bacillus spp. & $2(4.26 \%)$ \\
Alcaligenes faecalis & $1(2.13 \%)$ \\
\hline Total & $\mathbf{4 7 ( 1 0 0 \% )}$ \\
\hline
\end{tabular}

\section{Essential oils chemical composition by gas chromatography-mass spectrometry (GC-MS) analysis}

Table 2 shows the results of the GC-MS analysis of lemongrass, kaffir lime and holy basil essential oils. The results demonstrated that each of the tested essential oils did not share any main constituents. Lemongrass essential oil consisted of 4 main constituents: geranial $(45.32 \%)$, neral $(35.43 \%)$, myrcene $(7.88 \%)$ and geraniol $(4.12 \%)$. Kaffir lime essential oil consisted of 4 different main constituents: $\alpha$-pinene (25.58\%), DL-limonene (19.38\%), terpinene-4-ol (14.12\%) and $\beta$-terpineol $(12.24 \%)$, and holy basil essential oil consisted of another 3 main constituents: methyl eugenol, caryophyllene and eugenol at concentrations of 52.43, 29.29 and $8.68 \%$, respectively. 
Table 2. The chemical composition of lemongrass, kaffir lime and holy basil essential oils.

\begin{tabular}{llll}
\hline Essential oil & Retention time (min) & Component & Area (\%) \\
Lemongrass & 7.15 & Myrcene & 7.88 \\
& 18.11 & $\beta$-citral (neral) & 35.43 \\
& 18.65 & Geraniol & 4.12 \\
Kaffir lime & 19.48 & $\alpha$-citral (geranial) & 45.32 \\
& 6.62 & $\beta$-pinene & 25.58 \\
& 8.74 & DL-limonene & 19.38 \\
Holy basil & 15.43 & Terpinene-4-ol & 14.12 \\
& 16.11 & $\alpha$-terpineol & 12.24 \\
& 23.23 & Eugenol & 8.68 \\
& 25.73 & Methyl eugenol & 52.43 \\
\hline
\end{tabular}

\section{Antibacterial activity of essential oils by disc diffusion method}

The study of the antibacterial activity of tested essential oils against 34 isolates of CNS and 5 isolates of $S$. aureus by disc diffusion method showed that $10 \% \mathrm{v} / \mathrm{v}$ lemongrass, kaffir lime and holy basil essential oils produced inhibition zones with average diameters ranging from 7 to $31 \mathrm{~mm}$ (Table 3 ). The DMSO diluent control did not show any antibacterial activity (inhibition zone $\geq 6 \mathrm{~mm}$ ). Kaffir lime and holy basil essential oils had small average inhibition zone diameters for CNS (7.00 \pm 0.83 and $9.00 \pm 1.35 \mathrm{~mm}$, respectively) and S. aureus ( $9.00 \pm 0.83$ and $9.00 \pm 5.26 \mathrm{~mm}$, respectively). The lemongrass essential oil had much larger average inhibition zone diameters than the kaffir lime and holy basil essential oils, $25.00 \pm 1.75 \mathrm{~mm}$ for CNS and $31.00 \pm 6.61 \mathrm{~mm}$ for $S$. aureus $(P<0.05)$.

Table 3. The average inhibition zone diameters of essential oils against staphylococcal bacteria isolated from dairy goats with subclinical mastitis.

\begin{tabular}{lll}
\hline \multirow{2}{*}{$\begin{array}{l}\text { Essential oil(Concentration } \\
\text { of } \mathbf{1 0 \%} \mathbf{~ v / v )}\end{array}$} & \multicolumn{2}{c}{ Inhibition zone (mm) } \\
\cline { 2 - 3 } & CNS $(\mathbf{n}=\mathbf{3 4})$ & S. aureus $(\mathbf{n}=\mathbf{5})$ \\
Lemongrass & $25.00 \pm 1.75^{\mathrm{a}}$ & $31.00 \pm 6.61^{\mathrm{a}}$ \\
Kaffir lime & $7.00 \pm 0.83^{\mathrm{b}}$ & $9.00 \pm 0.83^{\mathrm{b}}$ \\
Holy basil & $9.00 \pm 1.35^{\mathrm{c}}$ & $9.00 \pm 5.26^{\mathrm{b}}$ \\
\hline
\end{tabular}

Note: Values represent the means of triplicate experiments \pm SD. Superscript letters within a column indicate statistically significant differences between the means $(P<0.05)$.

\section{Antibacterial activity of essential oils by broth microdilution method}

The results of the broth microdilution tests are shown in Table 4. Lemongrass essential oil had the highest antibacterial effect against both CNS and $S$. aureus, the $\mathrm{MIC}_{90}$ and $\mathrm{MBC}_{90}$ were 0.30 and $0.15-0.30 \% \mathrm{v} / \mathrm{v}$, respectively. The $\mathrm{MIC}_{90}$ values of kaffir lime and holy basil essential oil were 8-16 times higher than lemongrass essential oil and had the same $\mathrm{MIC}_{90}$ or $\mathrm{MBC}_{90}$ (2.50 and $>2.50 \% \mathrm{v} / \mathrm{v}$, respectively). 
Table 4. Minimum inhibitory concentration for $90 \%$ of tested samples (MIC 90 ) and minimum bactericidal concentration for $90 \%$ of tested samples (MBC 90 ) of lemongrass, kaffir lime and holy basil essential oils against staphylococcal bacteria isolated from dairy goats with subclinical mastitis.

\begin{tabular}{lllll}
\hline \multirow{2}{*}{ Essential oil } & \multicolumn{2}{c}{ CNS $(\mathbf{n}=\mathbf{3 4})$} & \multicolumn{2}{c}{ S. aureus $(\mathbf{n}=\mathbf{5})$} \\
\cline { 2 - 5 } & $\mathbf{M I C}_{\mathbf{9 0}}(\% \mathbf{v} / \mathbf{v})$ & $\mathbf{M B C}_{\mathbf{9 0}}(\% \mathbf{v} / \mathbf{v})$ & $\mathbf{M I C}_{\mathbf{9 0}}(\% \mathbf{v} / \mathbf{v})$ & $\mathbf{M B C}_{\mathbf{9 0}}(\% \mathbf{v} / \mathbf{v})$ \\
\hline Lemongrass & 0.30 & 0.30 & 0.15 & 0.30 \\
Kaffir lime & 2.50 & $>2.50$ & 2.50 & $>2.50$ \\
Holy basil & 2.50 & $>2.50$ & 2.50 & $>2.50$ \\
\hline
\end{tabular}

Note: Values represent the mode of experiments of 34 or 5 isolates.

\section{Time-kill kinetics of lemongrass essential oil against a $S$. aureus subclinical mastitis isolate}

Lemongrass essential oil was selected for the time-kill study as it had the highest antibacterial activity in disc diffusion and broth microdilution tests. The time-kill kinetics of lemongrass essential oil against one $S$. aureus subclinical mastitis isolate are presented in Figure 1. The lemongrass essential oil concentration of 10 times MIC 90 $(1.5 \% \mathrm{v} / \mathrm{v})$ had the eradication effect higher than 5 times $\mathrm{MIC}_{90}(0.75 \% \mathrm{v} / \mathrm{v})$ and 1 time MIC $90(0.15 \% \mathrm{v} / \mathrm{v})$ lemongrass essential oil and $0.54 \% \mathrm{w} / \mathrm{v}$ iodine solution. It was eradicated the tested bacteria about $99.99 \%$ (4-log reduction) within 30 min and more than $99.9999 \%$ (6-log reduction) within $1 \mathrm{~h}$. While the lemongrass essential oil concentration of 5 times MIC $90_{9}$ was given $99.9 \%$ (3-log reduction), $99.999 \%$ (5-log reduction) and more than $99.9999 \%$ reduction of the inoculum at $30 \mathrm{~min}, 1 \mathrm{~h}$ and $2 \mathrm{~h}$, respectively. For the 1 times MIC $_{90}$ lemongrass essential oil, it had eradication effect similar to $0.54 \% \mathrm{w} / \mathrm{v}$ iodine solution, which reduced the number of viable bacteria by $90 \%$ ( $1-\log$ reduction), 99.9\%, 99.999\% and more than $99.9999 \%$ at $30 \mathrm{~min}, 1 \mathrm{~h}, 2 \mathrm{~h}$ and $3 \mathrm{~h}$, respectively.

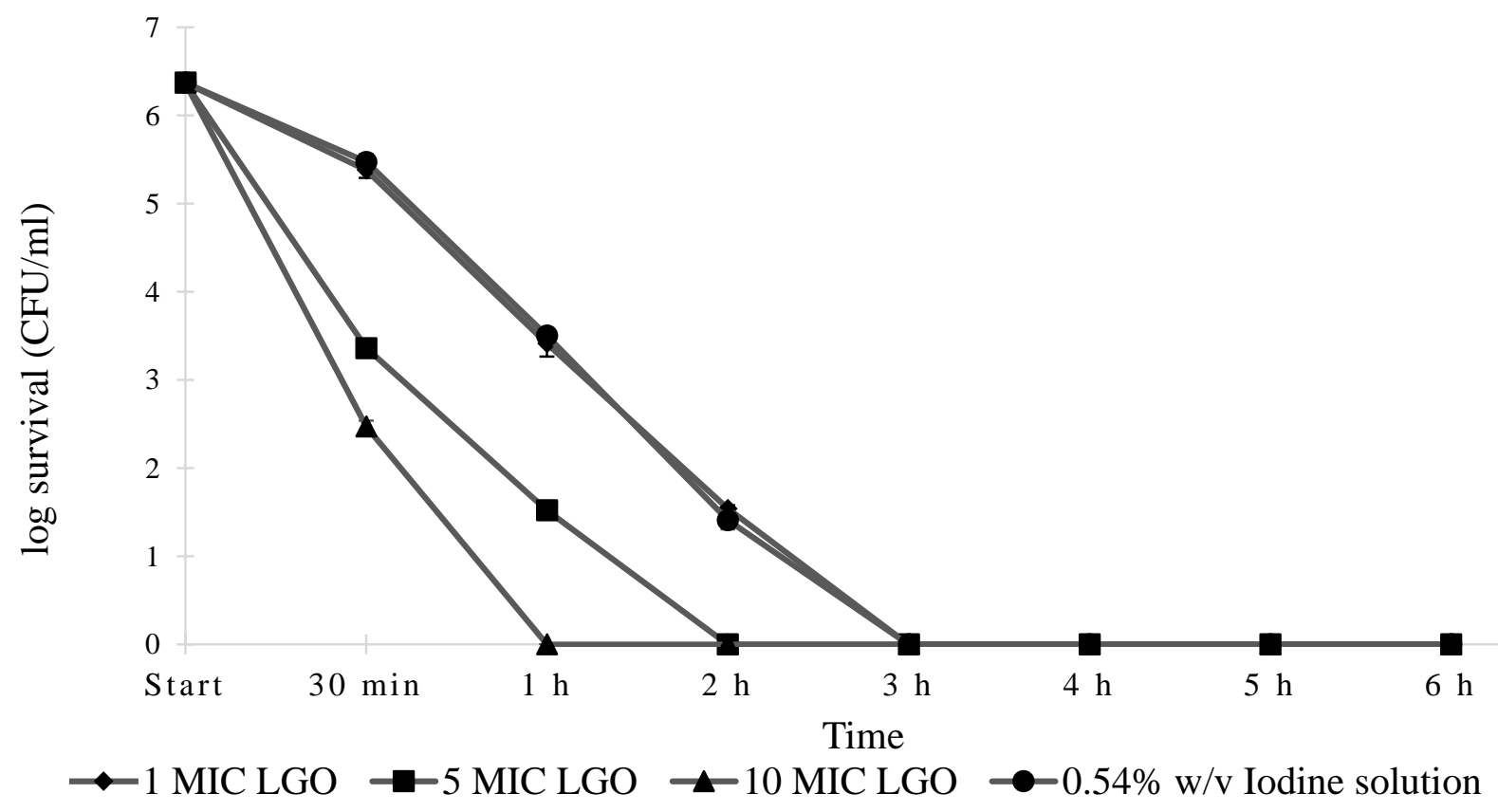

Figure 1. Time-kill assay of lemongrass essential oil (LGO) and iodine solution against $S$. aureus isolate. Values represent the means of triplicate experiments with error bars (SD). The MIC refer to $\mathrm{MIC}_{90} ; 1 \mathrm{MIC}=0.15 \% \mathrm{v} / \mathrm{v}, 5$ $\mathrm{MICs}=0.75 \% \mathrm{v} / \mathrm{v}, 10 \mathrm{MICs}=1.5 \% \mathrm{v} / \mathrm{v}$. 


\section{DISCUSSION}

The bacteria most commonly collected from subclinical mastitis in dairy goats in this study were CNS (72.34\%) and S. aureus (10.63\%). This result is consistent with previous studies that have reported CNS and S. aureus were found in 50-90\% and 5$37 \%$ of dairy goats with subclinical mastitis, respectively (da Silva et al., 2004, Taufik et al., 2008, Aydin et al., 2009, Santos Neto et al., 2009, and Virdis et al., 2010).

The GC-MS results showing the main chemical constituents of the three tested essential oils are also in agreement with previous studies. Citral has previously been reported to be the main constituent of lemongrass essential oil (75-82\%) (Masamba et al., 2003; Aiemsaard et al., 2010), while the main constituents of kaffir lime are limonene (20-40\%), terpinene-4-ol (10-14\%) and a-terpineol (about 13\%) (Aiemsaard et al., 2010; Srisukh et al., 2012). Aiemsaard et al. (2010) reported that methyl eugenol, caryophyllene and eugenol were the main constituents of holy basil essential oil (38, 26 and $16 \%$, respectively), which was different to the studies of Kumar et al. (2010) and Kumari and Agrawal (2011) who found only two main constituents; eugenol $61-75 \%$ and caryophyllene $11-12 \%$. The slight differences in composition between studies are likely to be due to differences in the source of the herbs, the harvest season and the parts of the plant used. Moreover, the conditions and method of extraction can influence the proportions of each constituent (Nurdjannah and Bermawie, 2012; Hemalatha et al., 2016).

The disc diffusion and broth microdilution tests demonstrated that lemongrass essential oil was a better antibacterial agent against the tested bacteria compared to kaffir lime and holy basil essential oil. Although no previous study has reported activity of essential oils against bacteria isolated from mastitis in dairy goats, some studies have reported the antibacterial effects of the essential oil against $S$. aureus isolated from mastitis in dairy cows. The report of Choi et al. (2012) showed that $10 \%$ lemongrass essential oil gave a $24 \mathrm{~mm}$ inhibition zone in a disc diffusion assay, which was 3 times higher than the same concentration of oregano essential oil (Oreganum vulgare). Also, Aiemsaard et al. (2011) reported MIC and MBC values for lemongrass essential oil against $S$. aureus isolated from cows with subclinical mastitis were $5.4 \% \mathrm{v} / \mathrm{v}$, much higher than the MIC/MBC values seen in this study, which may be due to differences in bacterial strains, test conditions or source of essential oil. The results in the current study also showed that $S$. aureus was slightly more susceptible to lemongrass essential oil than CNS, which is consistent with multiple other reports of increased resistance to antimicrobial agents in CNS (da Silva et al., 2004, Aydin et al., 2009, Santos Neto et al., 2009, and Virdis et al., 2010). Moreover, Okmen and Turkey (2013) studied the effect of methanolic extract of Elaegnus angustifolia against CNS and S. aureus isolated from mastitis in cows by disc diffusion and broth microdilution methods, and showed that CNS was more resistant than S. aureus, similar to the study of Gulten (2013) with ethanolic extract of Anthemis chia. Researchers have proposed that this decreased susceptibility in CNS may be due to the use of antibiotics in dairy farms causing resistance, especially in CNS bacteria, which is common skin flora and opportunistic pathogen.

Lemongrass essential oil at concentrations of $0.75-1.5 \% \mathrm{v} / \mathrm{v}$ reduced survival of bacteria in the time-kill assay by $99.90-99.99 \%$ within $30 \mathrm{~min}$, a higher reduction than $0.54 \% \mathrm{w} / \mathrm{v}$ iodine solution. Also, when the concentration of essential oil and contact time were increased, the antibacterial effect also increased. This is consistent with the report of Chamdit and Siripermpool (2012), who studied the effect of lemongrass and clove essential oils against S. aureus ATCC43300, and the report of Christensen and Anderson et al. (2017), who studied the effect of lemongrass essential oil and citral against $S$. aureus USA300.

The antibacterial activities of lemongrass essential oil are presumably due to the main components citral and geraniol. These two compounds affect the integrity of the bacterial cell wall leading to loss of transmembrane balance and cell death (Aiemsaard et al., 2011; Shi et al., 2016). In addition, citral reduces intracellular $\mathrm{pH}$ value and adenosine triphosphate (ATP) levels by increasing ATP hydrolysis and outflow of ATP hrough the injured cell membrane, which affects biological processes of the cells (Shi et al., 2016). Moreover, citral also reduces expression of the extracellular fibrinogen- 
binding protein $\mathrm{C}(\mathrm{efbC})$ gene, an important virulence factor of $S$. aureus (Christensen and Anderson, 2017).

\section{CONCLUSION}

Lemongrass, kaffir lime and holy basil essential oils had different antibacterial effects against CNS and $S$. aureus isolated from dairy goats with subclinical mastitis. Lemongrass essential oil showed the highest antibacterial activity and has potential to be developed as an antibacterial agent or teat dip formula to control subclinical mastitis in goats. Further studies are required to develop a suitable formulation and to determine the in vivo efficacy in experimental animals.

\section{ACKNOWLEDGEMENTS}

The authors thank Dr. Glenn Borlace, Faculty of Pharmaceutical Sciences, Khon Kaen University, for English language assistance.

\section{REFERENCES}

Adwan, M.G. 2006. Antibiotic resistance against Staphylococcal isolated covered from subclinical mastitis in the North of Palestine. The Islamic University Journal. 14: 1-9.

Aiemsaard, J., Aiumlamai, S., Aromdee, C., Taweechaisupapong, S., and Khunkitti, W. 2011. The effect of lemongrass oil and its major components on clinical isolate mastitis pathogens and their mechanisms of action on Staphylococcus aureus DMST 4745. Research in Veterinary Science. 91: e31-e37.

Aiemsaard, J., Aiumlamai, S., Taweechaisupapong, S., Aromdee, C., and Khunkitti, W. 2010. Chemical composition, antioxidant activity and antibacterial action of eight essential oils against clinical isolates of mastitis pathogens. International Journal of Essential Oil Therapeutics. 4: 37-43.

Ali, Z., Muhammad, G., Ahmad, T., Khan, R., Naz, S., Anwar, H., and Usama, A.R. 2010. Prevalence of caprine sub-clinical mastitis, its etiological agents and their sensitivity to antibiotics in indigenous breeds of Kohat, Pakistan. Pakistan Journal of Life and Social Sciences. 8: 63-67.

Amelia, B., Saepudin, E., Cahyana, A.H., Rahayu, D.U., Sulistyoningrum, A.S., and Haib, J. 2017. GC-MS analysis of clove (Syzygium aromaticum) bud essential oil from Java and Manado. AIP Conference Proceedings. 1862: 030082-1-030082-9.

Aydin, I., Kav, K., and Celik, H.A. 2009. Identification and antimicrobial susceptibility of subclinical mastitis pathogens isolated from hair goats' milk. Journal of Animal and Veterinary Advances. 8: 1086-1090.

Burt, S. 2004. Essential oils: their antibacterial properties and potential applications in foods-a review. International Journal of Food Microbiology. 94: 223-253.

Chamdit, S., and Siripermpool, P. 2012. Antimicrobial effect of clove and lemongrass oils against planktonic cells and biofilms of Staphylococcus aureus. Pharmaceutical Sciences Asia. 39: 28-36.

Choi, J.Y., Damte, D., Lee, S.J., Kim, J.C., and Seung, S.C. 2012. Antimicrobial activity of lemongrass and oregano essential oil against standard antibiotic resistant Staphylococcus aureus and field isolates from chronic mastitis cow. International Journal of Phytomedicine. 4: 134-139.

Christensen, C.J., and Anderson, K.L. 2017. Characterizing the antibacterial properties and transcriptional alterations induced by lemongrass oil in Staphylococcus aureus. The Journal of Experimental Microbiology \& Immunology. 3: 57-62.

Clinical and laboratory standard institute (CLSI). 2008. Reference method for broth dilution antifungal susceptibility testing of yeast; approve standard-third edition. CLS document M27-A3. 
Clinical and laboratory standard institute (CLSI). 2013. Performance standard for antimicrobial disk and dilution susceptibility tests for bacteria isolated from animals; approved standard-fourth edition. CLS document VET01-A4.

Conteras, A., Luengo, C., Sanchez, A., and Corrales, J.C. 2003. The role of intramammary pathogens in dairy goats. Livestock Production Science. 79: 273283.

da Silva, E.R., Siqueira, A.P., Martins, J.C.D., Ferreira, W.P.B., and da Silva, N. 2004. Identifivation and in vitro antimicrobial susceptibitlity of Staphylococcus species isolated from goat mastitis in the Northeast of Brazil. Small Ruminant Research. 55: 45-49.

Dahl, L., Opsahl, J.A., Meltzer, H.M., and Julshamn, K. 2003. Iodine concentration in Norwegian milk and dairy products. British Journal of Nutrition. 90: 679-685.

Dhifi, W., Bellili, S., Jazi, S., Bahloul, N., and Mnif, W. 2016. Essential oils' chemical characterization and investigation of some biological activities: a critical review. Medicines (Basel). 3: ID 25.

Gamboa, P.M. 2009. The epidemiology of drug allergy-related consultations in Spanish allergology services: Alergológica-2005. Journal of Investigational Allergology and Clinical Immunology. 19: 45-50.

Gulten, O. 2013. The antibacterial activity of Anthemis chia L. flower against mastitis pathogens and antioxidant capacity of the various extracts. Journal of Food Agriculture and Environment. 11: 795-799.

Hebert, V.R., Middleton, J.R., Tomaszewska, E., and Fox, L.K. 2003. Methodology for quantifying residues of chlorhexidine in raw dairy milk. Journal of Agricultural and Food Chemistry. 51: 567-570.

Hemalatha, R., Nivetha, P., Mohanapriya, C., Sharmila, G., Muthukumaran, C., and Gopinath, M. 2016. Phytochemical composition, GC-MS analysis, in vitro antioxidant and antibacterial potential of clove flower bud (Eugenia caryophyllus) methanolic extract. Journal of Food Science and Technology. 53: 1189-1198.

Islam, A., Samad, A., and Rahman, A.K.M.A. 2012. Prevalence of subclinical caprine mastitis in Bangladesh based on parallel interpretation of three screening tests. International Journal of Animal and Veterinary Advances. 4: 225-228.

Kumar, A., Shukla, R., Singh, P., and Dubey, N.K. 2010. Chemical composition, antifungal and antiaflatoxigenic activities of Ocimum sanctum L. essential oil and its safety assessment as plant based antimicrobial. Food and Chemical Toxicology. 48: 539-543.

Kumari, R., and Agrawal, S.B. 2011. Comparative analysis of essential oil composition and oil containing glands in Ocimum sanctum L. (Holy basil) under ambient and supplemental level of UV-B through gas chromatography-mass spectrometry and scanning electron microscopy. Acta Physiologiae Plantarum. 33:1093-1101.

Markey, B.K., Leonard, F.C., Archambault, M., Cullinane, A., and Maguire, D. 2013. Clinical Veterinary Microbiology. $2^{\text {nd }}$ ed. Missouri: Elsevier. $901 \mathrm{pp}$.

Masamba, W.R.L., Kamanura, J.F.M., Hennry Elizabeth, M.T., and Nyirenda, G.K.C. 2003. Extraction and analysis of lemongrass (Cymbopogon citratus) oil: An essential oil with potential to control the larger grain borer (Prostephanus truncatus) in stored products in Malawi. Malawi Journal of Agricultural Sciences. 2: $56-64$.

McDougall, S., Pankey, W., Delaney, C., Barlow, J., Murdough, P.A., and Scruton, D. 2002. Prevalence and incidence of subclinical mastitis in goats and dairy ewes in Vermont, USA. Small Ruminant Research. 46: 115-121.

Min, B.R., Pinchak, W.E., Merkel, R., Walker, S., Tomita, G., and Anderson, R.C. 2008. Comparativ antimicrobial activity of tannin extracts from perennial plants on mastitis pathogens. Scientific Research and Essays. 3: 066-073.

Mishra, A.K., Sharma, N., Singh, D., Gururaj, K., Abhishek, Kumar, V., and Sharma, D.K. 2018. Prevalence and bacterial etiology of subclinical mastitis in goats reared in organized farms. Veterinary World. 11: 20-24.

Mohammed, A.N. 2014. Assessing the antimicrobial resistance patterns and in vitro efficacy of three disinfectants as teat dip against iodine $(0.5 \%)$ resistant mastitogenic pathogens. International Journal of Current Advanced Research. 2: 946-953.

Nurdjannah, N., and Bermawie, N. 2012. Clove oil. In: Peter, K.V. editor. Handbook of Herbs and Spices. Cambridge: Woodhead Publishing. P.591-607. 
Okmen, G., and Turkey, O. 2013. The antibacterial of Elaeagnus angustifolia L. against mastitis pathogens and antioxidant capacity of the leaf metanolic extracts. Journal of Animal and Veterinary Advances. 12: 491-496.

Persson, Y., and Olofsson, I. 2011. Direct and indirect measurement of somatic cell count as indicator of intramammary infection in dairy goats. Acta Veterinaria Scandinavica. 53: 1-5.

Santos Neto, T.M., Mota, R.A., Silva, L.B.G., Viana, D.A., Lima-Filho, J.L., Sarubbo, L.A., Converti, A., and Porto, A.L.F. 2009. Susceptibility of Staphylococcus spp. isolated from milk of goats with mastitis to antibiotics and green propolis extracts. Letters in Drug Design \& Discovery. 6: 63-68.

Sharma, N., Mukherjee, R., Ingale, S.L. and Jadhav, R.K. 2010. Effect of Phyllanthus emblica on ceruloplasmin in bovine staphylococcal mastitis. Indian Council of Agricultural Research. 19(2): 19-24.

Shi, C., Song, K., Zhang, X., Sun, Y., Sui, Y., Chen, Y., Jia, Z., Sun, H., Sun, Z., and Xia, X. 2016. Antimicrobial activity and possible mechanism of action of citral against Cronobacter sakazakii. PLoS One. 11: ID e0159006.

Singh, T., Sharma, M., and Singh, G. 2018. Effect of post teat dip treatments for the prevention of mastitis in dairy cattle. Journal of Krishi Vigyan. 7: 98-100.

Srisukh, V., Bunyapraphatsara, N., Pongpa, A., Tungrugsasu, W., Puttipipatkhachorn, S., Oniam, W., Karawamitr, T., Bunsiriluk, S., and Thongbainoi, W. 2012. Fresh produce antibacterial rinse from kaffir lime oil. Mahidol University Journal of Pharmaceutical Sciences. 39: 15-27.

Taufik, E., Hildebrandt, G., Kleer, J.N., Wirjantoro, T.I., Kreausukon, K., and Pasaribu, F.H. 2008. Contamination level of Staphylococcus spp. in raw goat milk and associated risk factors. Media Peternakan. 31: 155-165.

Usman, M.S., Zowalaty, M.E.E., Shameli, K., Zainuddin, N., Salama, M., and Ibrahim, N.A. 2013. Synthesis, characterization, and antimicrobial properties of copper nanoparticles. International Journal of Nanomedicine. 8: 4467-4479.

Virdis, S., Scarano, C., Cossu, F., Spanu, V., Spanu, C., and Luigi De Santis, E.P. 2010. Antibiotic resistance in Staphylococcus aureus and coagulase negative staphylococci isolated from goats with subclinical mastitis. Veterinary Medicine International. 2010: ID517060.

Wakwoya, A., Molla, B., Belihu, K., Kleer, J., and Hildebrandt, G. 2006. A cross sectional study on the prevalence, antimicrobial susceptibility patterns and associated bacterial pathogens of goat mastitis. International Journal of Applied Research in Veterinary Medicine. 4: 169-176. 